\title{
PUMPING BEHAVIOR OF SPUTTERING ION PUMP *
}

T. S. Chou, J. Bittner, and J. Schuchman

National Synchrotron Light Source

BNL -46995

Brookhaven National Laboratory

DE92 007173

Upton, NY 11973

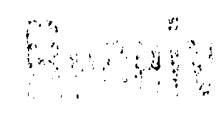

PEB U U WOE

To optimize the design of a distributed ion pump (DIP) for the Superconducting X-Ray Lithography Source (SXLS) the stability of the rotating electron cloud at very high magnetic field beyond transition ${ }^{1}$, must be re-examined. In this work the pumping speed and frequency spectrum of a DIP at various voltages ( 1 to $10 \mathrm{KV}$ ) and various magnetic fields (0.1 to 4 Tesla) are measured. Three cell diameters $10 \mathrm{~mm}, 5 \mathrm{~mm}$ and $2.5 \mathrm{~mm}$, each $8 \mathrm{~mm}$ long, and with 3 or $4 \mathrm{~mm}$ gaps between anode and cathode are investigated. In this study both the titanium cathodes and the stainless steel anode plates are perforated with holes comparable in size to the anode cell diameters. Only the partially saturated pumping behavior is under investigation. The ultimate pressure and conditioning of the pump will be investigated at a later date when the stability criterion for the electron cloud is better understood.

\section{INTRODUCTION}

The Distributed Ion Pump (DIP) for the Superconducting Lithography Source (SXLS) at the National Synchrotron Light Source (NSLS) will be operated from 1 Tesla, injection magnetic field, to 4 Tesla the storage field. DIP's are widely used for pumping in the bending magnets of many synchrotrons $s^{2,3,4,5,6,7}$ throughout the world. The pumping speed of the typical Sputter Ion Pump (SIP) beyond the Transition Magnetic Field (TMF) ${ }^{1}$ has been examined and is found to be greatly reduced far beyond TMF. The rotational frequency of the electron cloud ${ }^{8}$ has been

*Work performed under the auspices of U.S. DOE under contract DE-ACO2-76CH00016. 
used to characterize the pump behavior. Preliminary stability studies of the ion pump at a very wide range of voltages and magnetic fields is presented. A spectrum analyzer has been implement to facilitate the handling and analysis of data (frequency spectra). The results of detail analysis will be published in a forthcoming paper.

\section{THEORY}

The study of the pumping behavior of sputter ion pumps is basically the study of the electron cloud stability in a crossed field discharge at low pressure. Many attempts, both experimental ${ }^{3,8,9}$ and theoretical ${ }^{10,11}$, have not fully revealed the complete picture of the rotating electron cloud stability. For a general review on this type of discharge, the reader is referred to the 1969 review by Hooper ${ }^{2}$, the 1977 review by Balaceau and Popc vici ${ }^{13}$ and the most recent 1988 review by Redhead ${ }^{14}$. For the development of the pumping speed formula, the reader is referred to the paper by $\mathrm{Chou}^{2}$.

\section{EXPERIMENTAL}

Three different cell diameters $10 \mathrm{~mm}, 5 \mathrm{~mm}$ and $2.5 \mathrm{~mm}$, each $8 \mathrm{~mm}$ long, with 3 or $4 \mathrm{~mm}$ gaps between anode and cathode are investigated. The cathode and the anode plates are made of Ti 50A Titanium and 304 Stainless Steel respectively. Both electrodes are perforated with hole sizes comparable to the cell diameter as shown in Fig. 1. The experimental set-up consists of three major components, the 4 Tesla superconducting solenoid magnet, the pumping speed measuring facility, and the spectrum analyzer with its associated equipments. Fig. 2 shows the schematic diagram of the experimental apparatus. All of the 304 S.S. components of the test pump were vacuum degassed at $900^{\circ} \mathrm{C}$ for 2 hours and the titanium at $700^{\circ} \mathrm{C}$. Nitrogen was chosen as the test gas for the pumping speed study. Pumping speeds of the test pumps are evaluated by the throughput measurement: 


$$
\mathrm{Q} \quad=\mathrm{S} * \mathrm{P}(\mathrm{T})=\mathrm{C} *[\mathrm{P}(\mathrm{G})-\mathrm{P}(\mathrm{T})]
$$

where $\quad$ Q = Gas throughput in Torr*Liter/Sec.

S $\quad=$ Pumping speed in Liter/Sec.

$\mathrm{P}(\mathrm{T})=$ Pressure of the test chamber in Torr.

C $\quad$ = Conductance of the orifice in Liter/Sec.

$P(G)=$ Pressure of the gas chamber in Torr.

A $2.5 \mathrm{~cm}$ long $7.3 \mathrm{~mm}$ diameter copper cylinder is inserted around the anode high voltage cable but inside the outer conducting shield. This copper cylinder is electrically isolated both from the high voltage by a teflon spacer and from earth ground by a $18 \mathrm{~mm}$ gap between shield and the cylinder. The cylinder acts as a capacitor coupler to detect the frequencies generated from the ion pump under investigation. The frequency spectrum is taken either by an Eaton AILTECH 757 spectrum analyzer or a HP 7100 spectrum analyzer.

The typical procedure for measuring the pump characteristics is described as follows: After the test pump is fully assembled in a UHV manner, the test pump is inserted into a room temperature vacuum chamber within the cryostat of superconducting magnet. The vacuum system is then bake-out for 48 hours at $150^{\circ} \mathrm{C}$ with all gate valves open. A $100 \mathrm{l} / \mathrm{s}$ Turbomolecular pump is used for pumping down the system during bake out and conditioning the test pump, but it is isolated from the system by an all-metal gate valve during the pumping speed measurement. All active elements in the system are degased before the end of the baking cycle. The test gas is then introduced into the system. The pumping speed and the frequency spectra are taken after equilibrium is established for voltages ranging from $1 \mathrm{KV}$ to $10 \mathrm{KV}$ and for magnetic fields ranging from 0.2 Tesla to 4 Tesla. This step is repeated for pressures from $10^{-7}$ Torr to $10^{-9}$ Torr. 


\section{RESULTS \& DISCUSSION}

Fig. 3 shows the pumping speed for two different cell diameters vs. magnetic field at various pressure ranges. The fast rise of the pumping speed in the Low Magnetic Field (LMF) as magnetic field increase, is common for both cell diameters. The much gentler decay in pumping speed for the $10 \mathrm{~mm}$ diameter cell is interpreted as the result of a mismatch of the large cell diameter to the short cell length. The detail correlation of pump behavior to ion pump parameters (voltage, magnetic field, cell dimension, condition of the pumping surface) will be published in the near future after a careful analysis of the frequency spectra for the ion pumps under study. For example, Fig. 4 shows the preliminary results of the frequency spectra at various voltage of $5 \mathrm{~mm}$ diameter cell at a 5 kilogauss magnetic field.

\section{DISCLAIMUER}

This report was prepared as an account of work sponsored by an agency of the United States Government. Neither the United States Gnvernment nor any agency thereof, nor any of their employees, makes any warranty, express or implied, or assumes any legal liability or responsibility for the accuracy, completeness, or use'ulnesis of any information, apparatus, product, or process disclosed, or represents that its use would nop infringe privately owned rights. Reference herein to any specific commercial product, prockiss, or service by trade name, trademark, manufacturer, or otherwise does not necessarily constitute or imply its endorsement, recommendation, or favoring by the United States Govern ment or any agency thereof. The views and opinions of authors expressed herein do not nipcessarily state or reflect those of the United States Government or any agency thereof. 


\section{ACKNOWLEDGMENT}

The authors would like to acknowledge the administrative help from the NSLS vacuum group, especially Mr. H. Halama. One of the authors (T. S. Chou) would like to acknowledge the excellent workmanship from Mr. C. Lanni, F. Porfido and P. J. Pietraski 


\section{REFERENCES}

1. W. Schuurman, Physica, 43, 513 (1969)

2. T. S. Chou, JVST, A5, 3446 (1987)

3. H. Hartwig and J. S. Koupsidis, JVST, 11, 1154 (1974)

4. R. J. Reid and B. A. Trickett, Proc. 7th Vac. Cong. \& 3rd Intern. Conf. Solid Surface (Vienna, 1977) p. 89

5. J. M. Laurent, O. Grobner, IEEE Vol. HS-26, 3. (1979)

6. H. Pingel and L. Schultz, IEEE 8th Int. Vacuum Congress, (Cannes, 1980) p. 147.

7. M. D. Malev and E. M. Trachtenberg, Vacuum, 23, 403 (1973)

8. R. L. Jepsen, Jour. Appl, Phys., 32, 2619 (1961)

9. J. H. Malmberg and C. F. Driscoll, Phys. Rev. Lett., 44,654 (1980)

10. R. H. Levy, Phys. Fluids, 11, 920 (1968)

11. R. F. Mukhamedov, Sov. Phys. Tech. Phys., 18, 1057 (1974)

12. E. B. Hooper, Adv. Electronics and Electron Physics, 27, 295 (1969)

13. M. Balaceau and C. Popovici, Studii Si Cercetari de Fdizica, 29, 1057 (1977).

14. P. A. Redhead, Vacuum, 38, 901 (1988) 


\section{FIGURE CAPTION}

Fig. 1. The configuration of the test Sputter Ion Pump

$s=$ cell size of the test pump, $g=$ gap between the anode and the cathodes

$\mathrm{Ti}=$ Titanium, S.S. $=$ Stainless Steel, $\ell=$ the length of the anode

Fig. 2. The experimental set-up. BAG - Bayard Alpert gauge

TMP = Turbomolecular pump. RT = Room Temperature. P.S. - Power Supply

Fig. 3 The Pumping Speed vs. Applied Magnetic field at two different pressure regions for $5 \mathrm{~mm}$ and $110 \mathrm{~mm}$ cell sizes.

Fig 4. Frequency Spectra of $5 \mathrm{~mm}$ cell at 5 kilogauss for different high voltage settings. The dash line is the "expected" linear regression from the most intense peaks of the Frequency Spectra.

$$
\begin{aligned}
& S=\text { pumping speed. H.V. = High Voltage } \\
& \ell / \mathrm{s}=\text { liters } / \text { sec. } \mathrm{KV}=\text { Kilovolts. } \mathrm{B}=\text { Magnetic field } \\
& \phi=\text { cell size. } \mathrm{KG}=\text { kilogauss. } \mathrm{mm}=\text { milimeter } \\
& \mathrm{GHz}=\text { Giga Hertz }=10^{9} \mathrm{cycleo} / \mathrm{sec}
\end{aligned}
$$




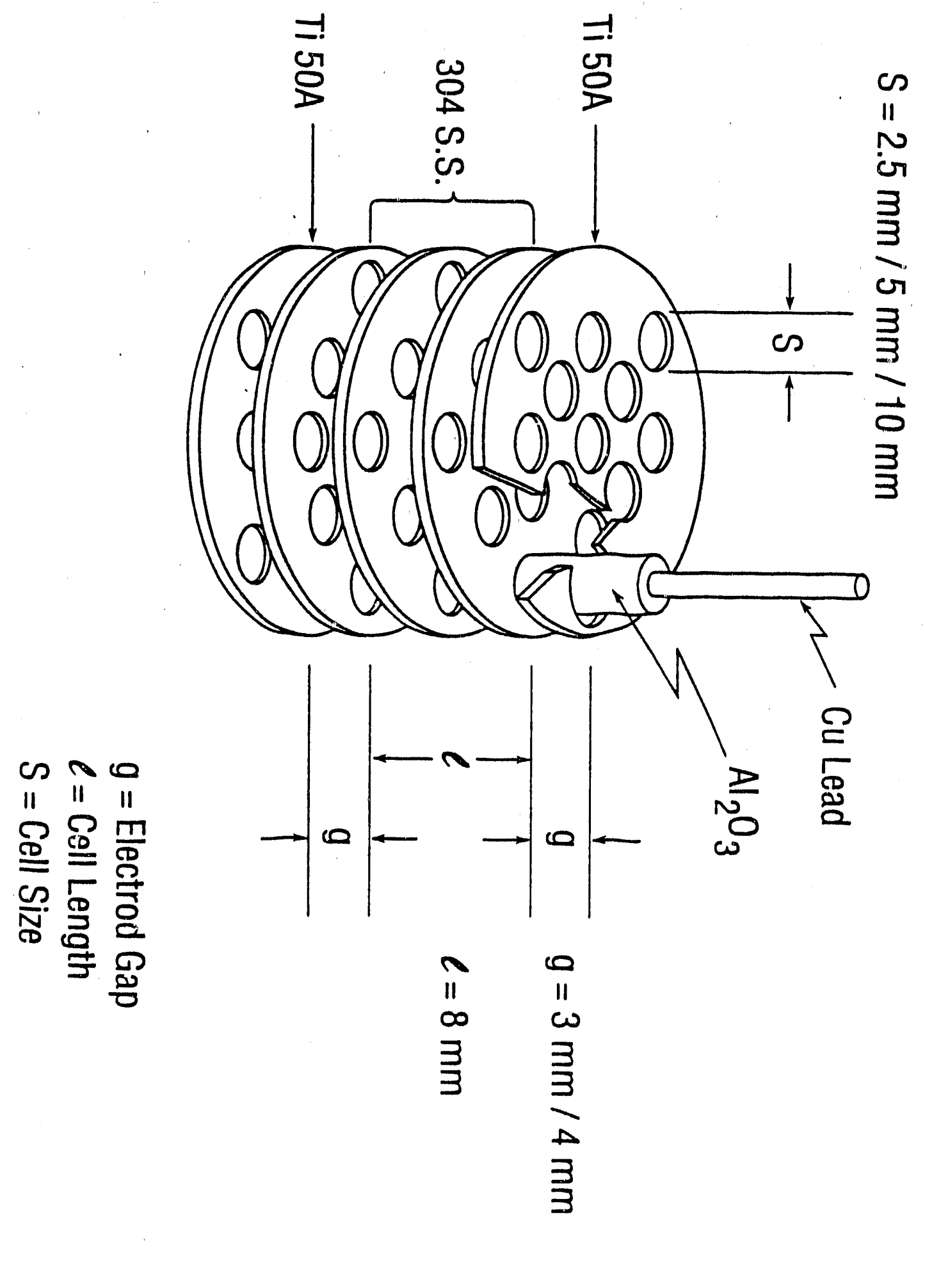




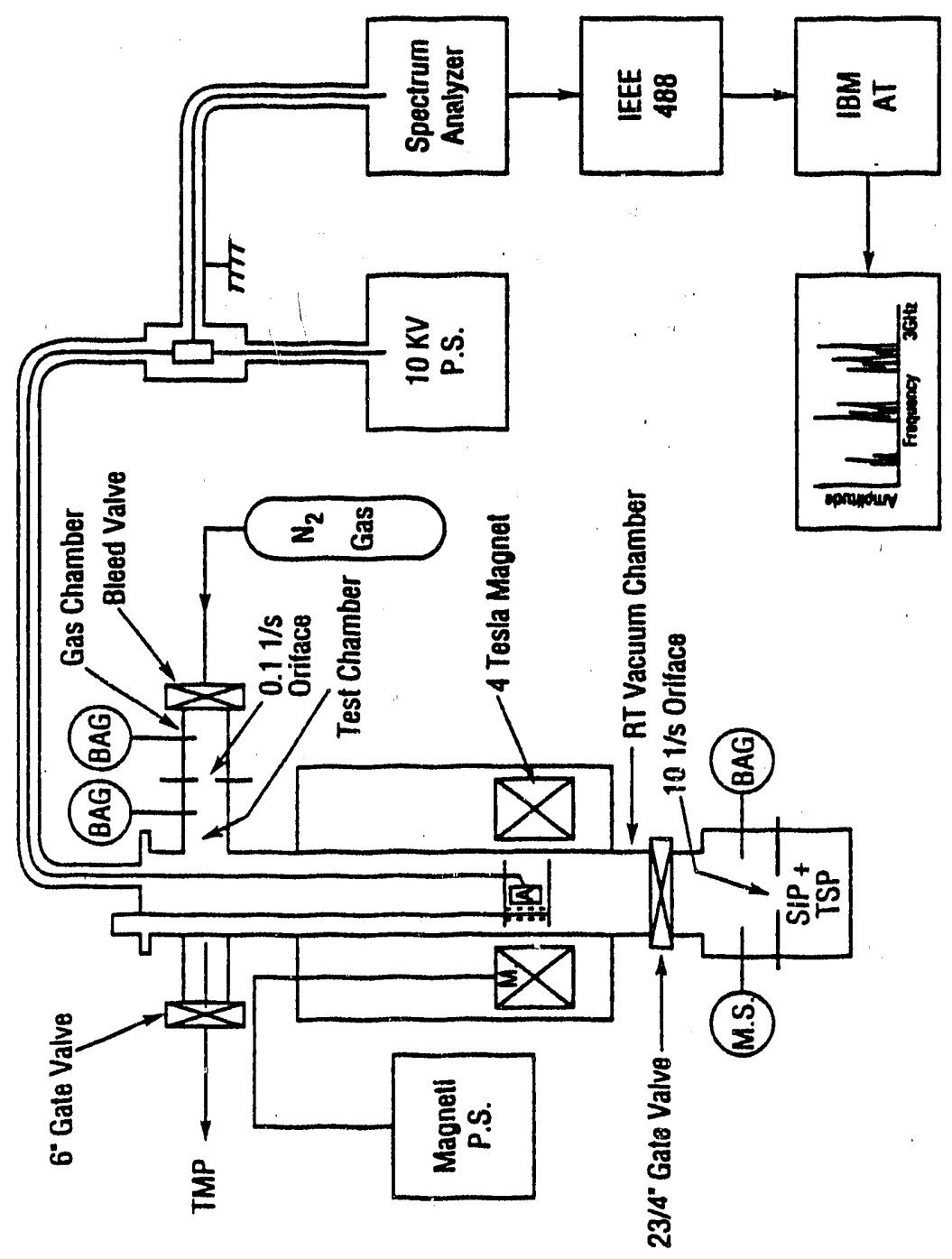




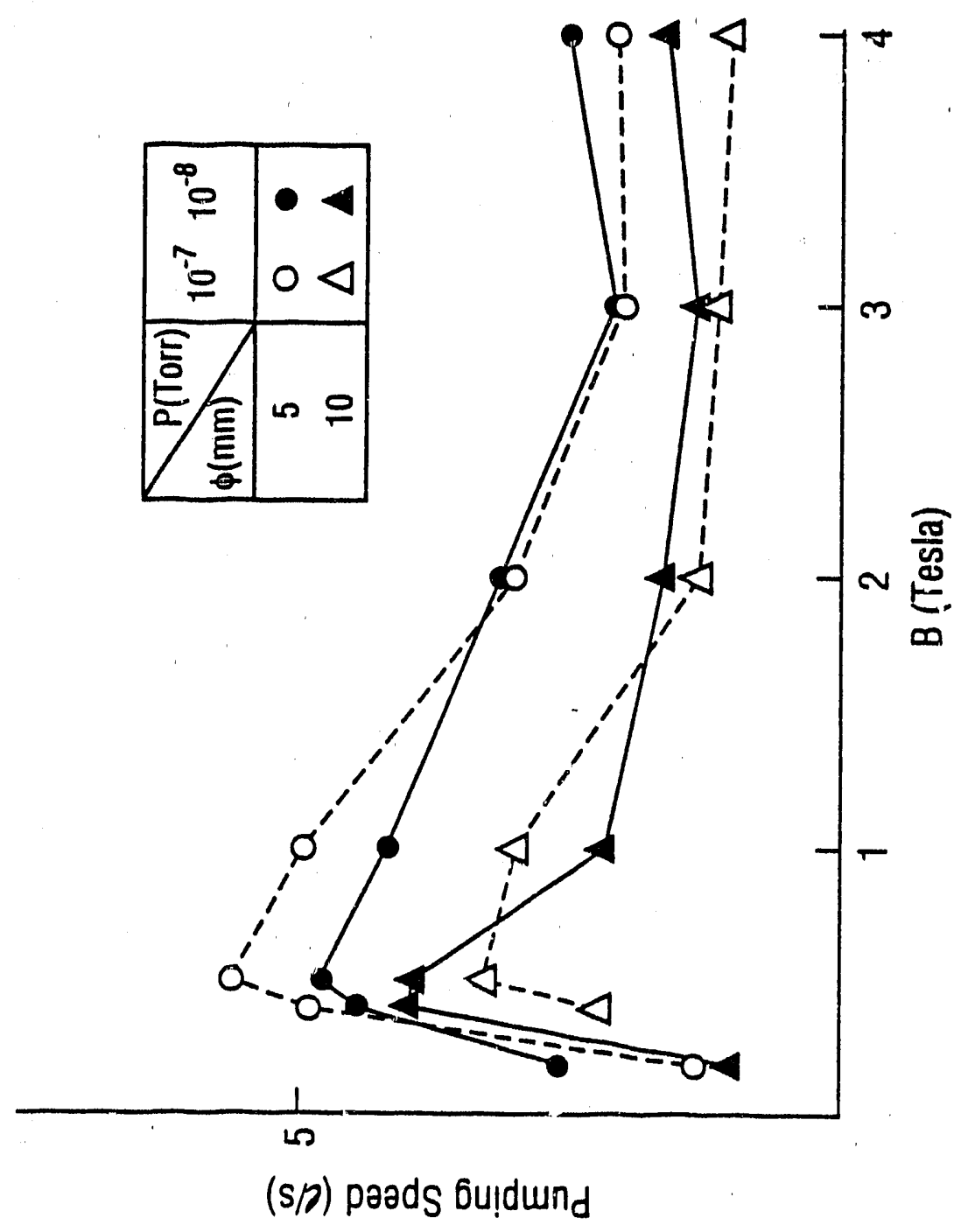




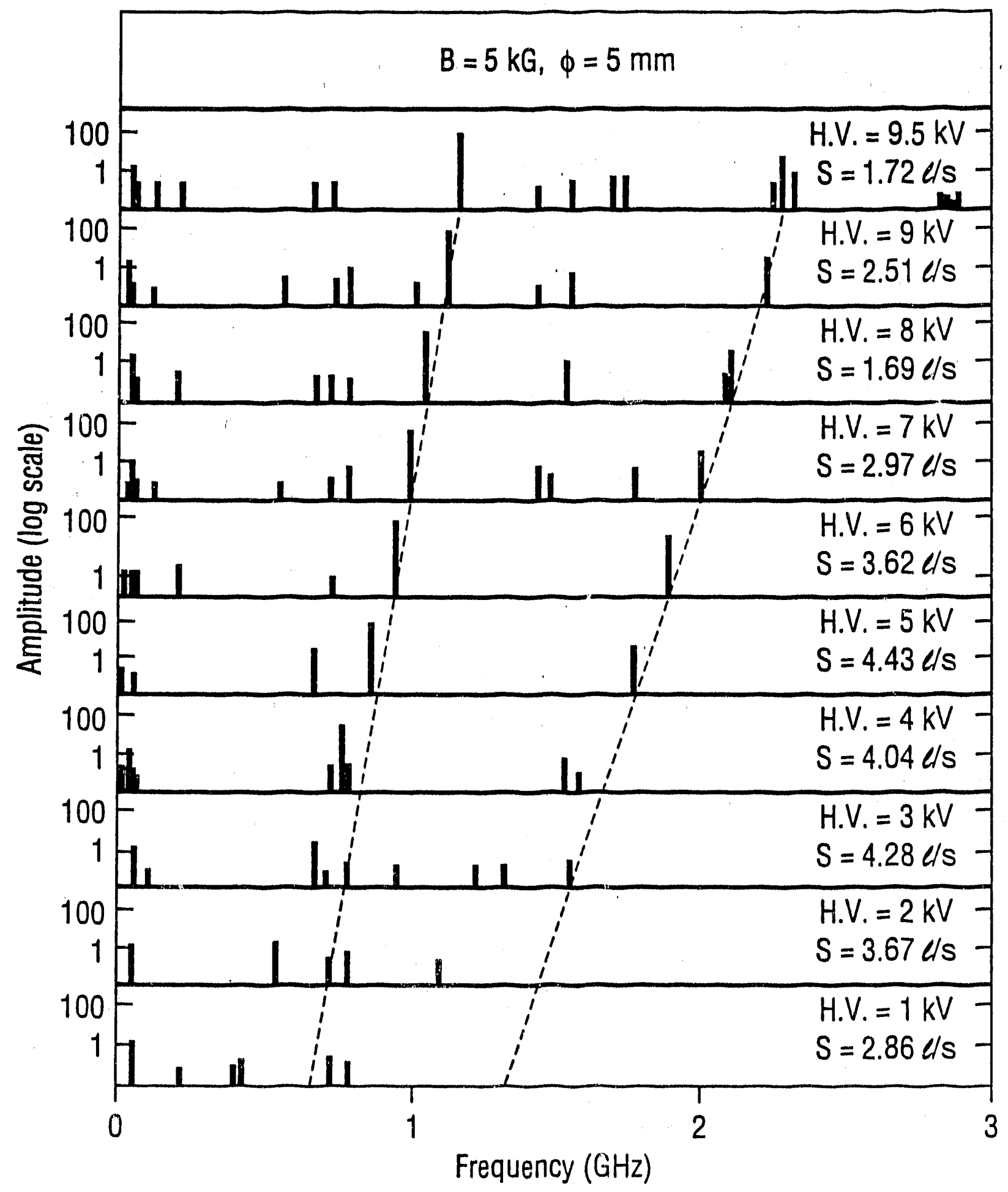



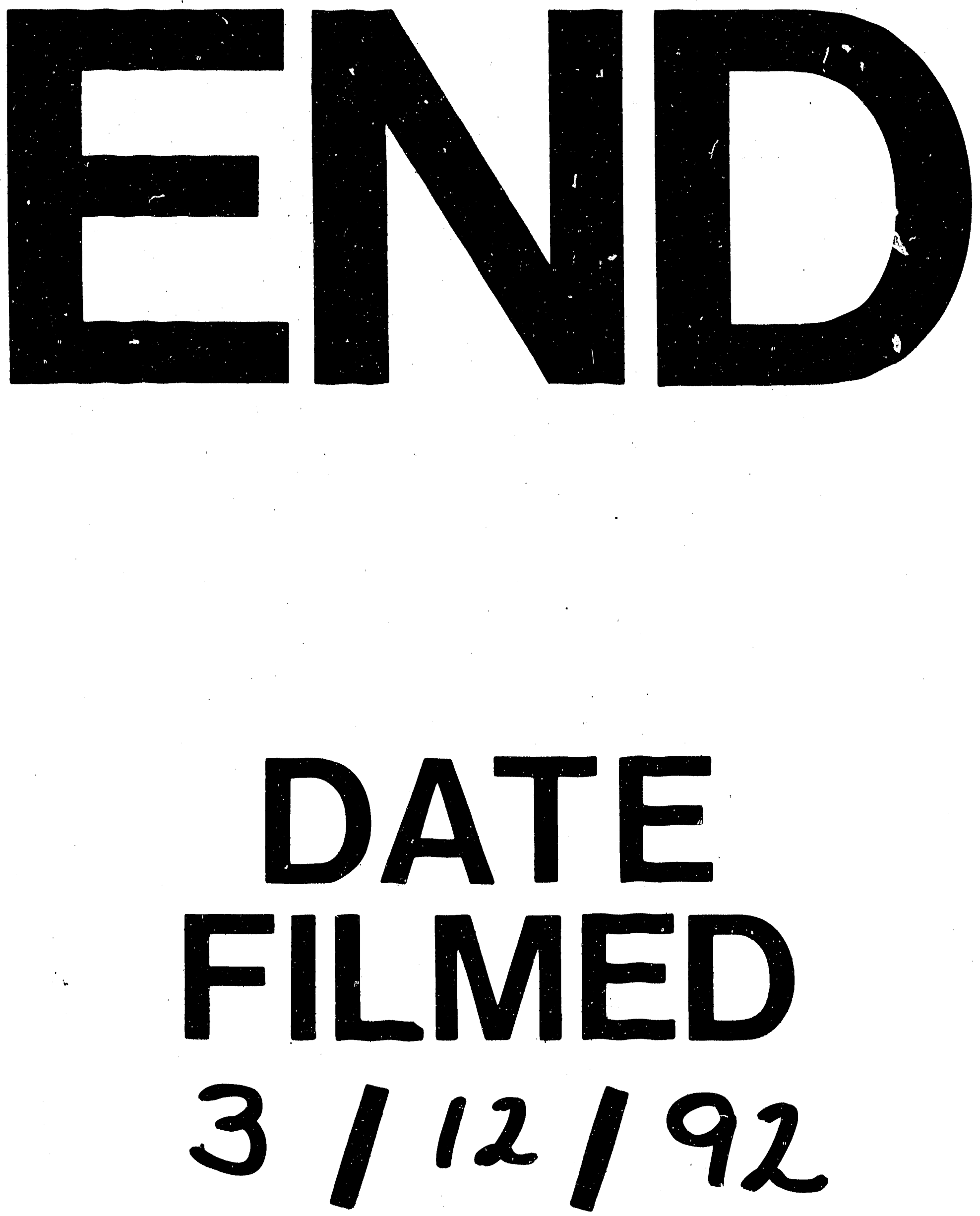